\title{
METABOLIC PROFILE COMPARISON BETWEEN FOLLICULAR FLUID AND SERUM IN NORMAL COWS AND THOSE AFFECTED BY OVARIAN CYSTS
}

\author{
Nora Mimoune ${ }^{1,2}$, Rachid Kaidi ${ }^{2,3}$, Mohammed Hocine Benaissa ${ }^{4}$, Mohamed Wail Bahouh ${ }^{1}$, \\ Ratiba Baazizi ${ }^{1}$, Mohamed Yassine Azzouz ${ }^{2}$ \\ ${ }^{1}$ National High School of Veterinary Medicine, Bab-Ezzouar, Algiers, Algeria \\ ${ }^{2}$ Institute of Veterinary Sciences, LBRA, University of Blida 1, \\ PB 270, Soumaa, Blida, Algeria \\ ${ }^{3}$ School of Veterinary Medicine and Science, University of Nottingham, Nottingham, \\ Leicestershire, United Kingdom \\ ${ }^{4}$ Scientific and Technical Research Centre for Arid Areas (CRSTRA), \\ Biophysical Station, Touggourt, Algeria
}

Received 2 March 2018; Received in revised form 12 July 2018; Accepted 18 September 2018

\begin{abstract}
The aim of this study was to carry out the metabolic profile comparison between follicular fluid and serum in normal cows and those affected by ovarian cysts (OC). After slaughtering, blood samples and follicular fluids from normal and cystic animals were collected and assayed using commercial kits to determine the concentrations of metabolites (glucose, total protein, total cholesterol, cortisol, triglycerides, urea, creatinine and insulin) and the liver enzymes activity. Data showed that $\mathrm{OC}$ were characterized by low levels of glucose, total protein, cholesterol and cortisol in cystic fluid, while urea concentrations were high compared to normal follicular fluid $(\mathrm{P}<0.001)$. On the other hand, serum assays of cystic animals revealed very low values of insulin and urea, whereas cortisol levels were relatively high in comparison with the serum of normal cows $(\mathrm{P}<0.001)$. Significant correlations between the serum and follicular fluid concentrations of normal cows were found for glucose $(r=0.49)$, total cholesterol $(r=0.31)$, cortisol $(r=0.38)$ and total protein $(r=0.63)$. The highest correlation was found for urea $(\mathrm{r}=0.86)$. On contrary, weak correlations were observed between metabolites concentrations in cystic fluid and in serum for normal and cystic cows. In conclusion, OC grow and persist in a metabolic environment, which differs from follicular fluid to blood. These changes may act together and/or separately to ensure the continuous development of OC. To understand a part of the mechanism, the authors propose a deep study about blood-follicle-barrier.
\end{abstract}

Key words: ovarian cyst, follicular fluid, serum, metabolic profile.

\section{INTRODUCTION}

It is well documented that follicular fluid has an important role in metabolic activity in association with follicular cells. This activity, as well as the

Corresponding author: Dr. Nora Mimoune, $\mathrm{PhD}$

E-mail address: nora.mimoune@gmail.com

Present address: National High School of Veterinary Medicine,

Bab-Ezzouar, Algiers, Algeria

Phone: +++:+213790901606

Copyright: (C) 2018 Mimoune N. This is an open-access article published under the terms of the Creative Commons Attribution License which permits unrestricted use, distribution, and reproduction in any medium, provided the original author and source are credited.

Competing Interests: The authors have declared that no competing interests exist.

Available Online First: 30 December 2018

Published on: 15 March 2019

https://doi.org/10.2478/macvetrev-2018-0030 properties of the blood-follicle barrier may change significantly during follicular growth and ovarian diseases (1). Modifications of the metabolites concentrations (glucose, urea, cholesterol, triglycerides, albumin, and total proteins), as well as the activity of lysosomal enzymes in the follicular fluid were involved in the integrity of both the metabolism and the membrane of follicular cells that could reflect the status of the follicle (2). However, the impact of the metabolic changes on the components with biological interest in OC was not fully understood. Therefore, it is necessary to determine the concentrations of the most common metabolites in follicular fluid in the physiological and pathological cases, but it is also important to 
know if these concentrations differ from those found in blood. Therefore, the aim of this study was to evaluate the balance in some metabolites (glucose, urea, total protein, cortisol, cholesterol, insulin) between the vascular compartment and follicular fluid in normal and cystic animals.

\section{MATERIAL AND METHODS}

\section{Animals and samples collection}

The study was conducted at a local abattoir in Algeria (El-Harrach abattoir, Algiers). Sixty nonpregnant dairy cows from different breeds (Holstein Friesian, Montbeliard, and crossed breeds), were used in this study. At post-mortem examination, no macroscopic abnormality in the reproductive tract of the cows was detected. Ovaries with $(\mathrm{n}=30)$ or without $(\mathrm{n}=30)$ cysts were immediately collected and put into separate plastic bags, while the blood samples from each animal were collected into capped disposable plastic tubes by jugular venipuncture. After collection, all samples were placed on ice and transferred to the laboratory within 30 to 40 minutes after slaughtering. The blood serum was separated by centrifugation ( 3.000 $\mathrm{rpm} / 20 \mathrm{~min}$ ) and stored at $-20^{\circ} \mathrm{C}$ until analyses.

During the dissection of the ovaries, the follicular diameter was measured with calipers and follicular fluid from each follicle was aspirated and stored separately at $-20^{\circ} \mathrm{C}$. Only follicles that appeared macroscopically and microscopically healthy (i.e., well vascularized and with a transparent follicular wall and fluid) and whose diameter was $>10 \mathrm{~mm}$ were used and classified as large follicles, as previously described (3). Ovarian cysts were diagnosed when the follicles were more than $25 \mathrm{~mm}$ in diameter, in the absence of a functional corpus luteum in either the right or the left ovary (4).

All applicable international, national, and/or institutional guidelines for the care and the use of the animals were followed. The study was approved by the National High School of Veterinary Medicine of Algiers and the Laboratory of Reproductive Biotechnologies of Blida University, Algeria.

\section{Biochemical and hormonal analyses}

Follicular and cystic fluids as well as blood samples were assayed for glucose, cholesterol, total protein, triglycerides, urea, creatinine, aspartate aminotransferase (AST), alanine aminotransferase (ALT), gamma glutamyl trans peptidase (GGT) by spectrophotometric methods with the help of a clinical chemistry auto-analyzer, Architect plus, ci 4100 (Architect c Systems, Abott Diagnostics, Germany). The intra- and inter-assay coefficients of variation for all analyses were below 5\%.

Insulin and cortisol serum measurement was performed on Cobas e411 by electrochemiluminescence with a human commercial kit applied to cattle (Roche Diagnostics GmbH, Germany) (5). The minimum detection limit was $0.5 \mathrm{nmol} / 1$ for cortisol and $0.2 \mu \mathrm{U} / \mathrm{ml}$ for insulin. All measurements were carried out according to the manufacturer's instructions.

\section{Statistical analyses}

Statistical analysis was performed using the STATISTICA software (Version 10, Stat Soft France, 2003). Statistical differences in the concentrations of metabolic serum parameters between the normal and the cystic cows and between follicular and cystic fluid, as well as the comparison of metabolites rate between the vascular compartment and the follicular fluid were carried out using Student's t-test. Correlation coefficients between serum and follicular fluid of normal and cystic cows were performed to compare the metabolites concentrations and to study the balance in these two biological liquids in normal and cystic conditions. Data were expressed as mean \pm standard deviation (SD). The results were considered significant when $\mathrm{P}<0.05$.

\section{RESULTS}

The mean follicular fluid concentrations of the different biochemical constituents in the ovarian cysts and large follicles are presented in Table 1. To interpret the results, reported and/or established values of these metabolites in previous studies were also mentioned.

Data presented in Table 1 revealed that cystic fluid had greater urea concentrations compared to follicular fluid. In contrast, glucose, total protein, total cholesterol and cortisol concentrations were less in cystic fluid than in normal one $(\mathrm{P}<0.05)$. Nevertheless, the difference in insulin, creatinine, GGT, AST and ALT concentrations between the two groups was not significant $(\mathrm{P}<0.05)$.

Results of the blood metabolic parameters are summarized in Table 2. They are expressed as mean \pm standard deviation. The reported and/or established values of these metabolites in previous studies were also mentioned. 
Table 1. Average concentrations ( \pm SD) of different metabolic parameters in follicular and cystic fluid of cows

\begin{tabular}{|c|c|c|c|}
\hline & Large follicle $(n=40)$ & Ovarian cyst $(n=40)$ & Reference range \\
\hline Glucose (g/l) & $0.56 \pm 0.11$ & $0.18 \pm 0.15^{* * *}$ & $0.4-0.7^{(3)}$ \\
\hline Insulin $(\mu \mathrm{UI} / \mathbf{m l})$ & $1.55 \pm 0.22$ & $1.49 \pm 0.36^{\mathrm{ns}}$ & $0-5^{(6)}$ \\
\hline Total protein (g/l) & $74 \pm 4.33$ & $60.52 \pm 6.39^{* * *}$ & $64-87^{(3)}$ \\
\hline TG (mmol/l) & $0.16 \pm 0.01$ & $0.14 \pm 0.01^{\text {ns }}$ & $0.14-0.25^{(3)}$ \\
\hline Cortisol (nmol/l) & $31.05 \pm 4.56$ & $15.06 \pm 6.25^{* * *}$ & $33-55^{(7)}$ \\
\hline GGT (U/I) & $20.98 \pm 3.98$ & $22.41 \pm 2.58^{\mathrm{ns}}$ & $17-24.1^{(8)}$ \\
\hline $\operatorname{AST}(\mathbf{U} / \mathbf{l})$ & $115 \pm 19.13$ & $119 \pm 30.50^{\mathrm{ns}}$ & $78-154^{(9)}$ \\
\hline $\operatorname{ALT}(\mathrm{U} / \mathbf{l})$ & $78 \pm 16.32$ & $81.23 \pm 18.69^{\mathrm{ns}}$ & $11-85.50^{(9)}$ \\
\hline Chol (mmol/l) & $1.44 \pm 0.58$ & $0.85 \pm 0.13^{* *}$ & $1.04-1.93^{(3,8)}$ \\
\hline Creatinine $(\mu \mathrm{mol} / \mathrm{l})$ & $126.74 \pm 90.08$ & $124.32 \pm 80.24$ ns & $103-155^{(8,10)}$ \\
\hline Urea (mmol/l) & $4.87 \pm 1.6$ & $6.50 \pm 1.02^{* * *}$ & $4.13-6.05^{(3,11)}$ \\
\hline
\end{tabular}

TG: triglycerides, ALP: Alkaline phosphatase, Chol: total cholesterol, AST: Aspartate Amino Transferase, ALT: Alanine Amino Transferase, GGT: Gamma Glutamyl Transpeptidase.

P values: ns: Not significant; *: $\mathrm{P}<0.05 ; * *: \mathrm{P}<0.001 ; * * *: \mathrm{P}<0.0001$

Table 2. Metabolic profile of cystic cows compared with normal animals and reference range

\begin{tabular}{llll}
\hline Parameter & Cystic cows & Normal cows & Reference range \\
\hline Glucose (mmol/l) & $2.89 \pm 0.15$ & $4.06 \pm 1.13^{* * * *}$ & $2.1-5.56^{(3,11)}$ \\
Insulin $(\boldsymbol{\mu U I} / \mathbf{m l})$ & $2.04 \pm 1.11$ & $8.66 \pm 1.46^{* * *}$ & $4.92-11.25^{(13)}$ \\
TP $(\mathbf{g} / \mathbf{l})$ & $79.38 \pm 6.97$ & $81 \pm 7.45^{\mathrm{ns}}$ & $70-94^{(2,3)}$ \\
TG (mmol/l) & $0.18 \pm 0.10$ & $0.19 \pm 0.09^{\mathrm{ns}}$ & $0.06-0.2^{(3,11)}$ \\
Chol (mmol/l) & $3.40 \pm 0.22$ & $3.48 \pm 1.01^{\mathrm{ns}}$ & $1.3-8^{(3)}$ \\
Cortisol (nmol/l) & $48.88 \pm 17$ & $32 \pm 09^{* * * *}$ & $11.59-92.46^{(3,14)}$ \\
AST (U/l) & $120 \pm 23.29$ & $122 \pm 46.58^{\mathrm{ns}}$ & $56-176^{(2)}$ \\
ALT (U/l) & $28 \pm 3.12$ & $25.69 \pm 1.58^{\mathrm{ns}}$ & $11-40^{(16)}$ \\
GGT (U/l) & $20.78 \pm 3.69$ & $22 \pm 5.14^{\mathrm{ns}}$ & $17-51^{(2,12)}$ \\
Urea (mmol/l) & $1.43 \pm 1.33$ & $4.45 \pm 1.02^{* * *}$ & $3.3-6.06^{(3,11)}$ \\
Creatinine( $\boldsymbol{\mu m o l} / \mathbf{l})$ & $155 \pm 32$ & $158 \pm 25.36^{\mathrm{ns}}$ & $88.4-240^{(15)}$ \\
\hline
\end{tabular}

TP : total protein ; TG : triglycerides ; Chol : total cholesterol ; AST : aspartate aminotransferase ;

ALT : alanine aminotransferase; GGT : gamma glutamyl transpeptidase.

$\mathrm{P}:$ ns: Not significant $(\mathrm{P}>0.05), * * *: \mathrm{P}<0.0001$

The results (shown in Table 2) demonstrated that cystic cows had significantly low levels of glucose than normal ones. However, the mean values were within the normal range in both groups. Insulin and urea levels were very low in cystic cows and were below the normal range, while in normal cows, the values were in the reference range. In contrast, the cortisol levels were higher in cystic cows compared with normal cows, but the values remain within the reference range. No significant differences in blood concentrations of total protein, cholesterol, triglycerides, creatinine and liver enzymes activity (AST, ALT, and GGT) between cystic and normal cows were recorded and the all values were within the accepted range.

According to the data shown in table 1 and 2, OC were characterized by low levels of glucose, total protein, cholesterol and cortisol in cystic fluid while the urea concentrations were high. On the other hand, serum analysis of cystic animals revealed very low values of insulin and urea, with relatively high cortisol levels. Data interpretation will be facilitated by statistical analysis that will examine the relationship between vascular compartment and follicular fluid in physiological and pathological condition (OC). Table 3 elucidated 
Table 3. Correlation coefficients (r's) between metabolite concentrations in follicular/cystic fluid and serum for each animal

\begin{tabular}{lllllll}
\hline Correlation $(\mathbf{r})$ & Glucose & Insulin & Total Protein & Urea & Cortisol & Cholesterol \\
\hline Serum NC-FF & $0.49^{*}$ & $0.27^{* * *}$ & $0.63^{* * *}$ & $0.86^{\text {ns }}$ & $0.38^{\text {ns }}$ & $0.31^{* *}$ \\
Serum NC-CF & $0.14 * * *$ & $0.02^{* * *}$ & $0.22^{* * *}$ & $0.33^{* * *}$ & $0.26^{* * *}$ & $0.20^{* * *}$ \\
Serum CC-CF & $0.02^{* * *}$ & $0.12^{*}$ & $0.19^{* * *}$ & $0.2^{* * *}$ & $0.09^{* * *}$ & $0.12^{* * *}$ \\
\hline
\end{tabular}

NC: Normal cows; FF: Follicular fluid; CF: Cystic fluid; CC: Cystic cows.

$\mathrm{P}$ values: ns: Not significant; *: $\mathrm{P}<0.05$; **: $\mathrm{P}<0.001$; ***: $\mathrm{P}<0.0001$.

the relationship between follicular fluid and serum of various metabolic parameters in normal and cystic cows.

Significant correlations between serum and follicular fluid concentrations of normal cows were found for glucose, total cholesterol, cortisol and total protein. The highest correlation was for urea. Weak correlations were observed between metabolites concentrations in the cystic fluid and in the serum for normal and cystic cows.

\section{DISCUSSION}

As far as we know, the current study represents the first investigation of the balance between the vascular compartment and follicular fluid in OC. Good understanding of the aetiopathogenesis of the ovarian cysts involves taking into consideration the characteristics of cystic fluid.

In general, follicular fluid is a complex fluid, yellow, semi-viscous, favorable to the growth and the differentiation of follicular cells and nuclear and cytoplasmic oocyte maturation. Its components are mainly from blood plasma, but it is also composed of factors produced locally by the granulosa and theca cells $(17,18)$. In general, it contains electrolytes, oxygen, hormones, energy substrates and metabolites (19). In ovarian cysts, the fluid becomes dark, viscous (20) and it is characterized by increased levels of some components that may reflect the degree of maturation of OC, but also indicate the means by which they persist.

Glucose concentrations in the follicular fluid were significantly lower than those found in the serum. This result agrees with those reported by Leroy et al. (3) in cattle, Arshad et al. (21) in buffaloes, and El-Bahr et al. (22) in camels. Similarly, Leroy et al. (3) observed a good correlation between the follicular fluid and the serum and suggested that hypoglycemia can reduce the intrafollicular glucose levels. Indeed, it is useful to note that the glucose content in the follicular fluid comes from glycolysis occurring in the granulosa cells and the flow of this plasma metabolite into the follicle $(1,3)$. Therefore, we can interpret the low levels of glucose in the cystic fluid not only by post-mortem changes that can induce conversion of glucose to lactate by anaerobic glycolysis, but also by the decreased influx of blood glucose. This is consistent with the results in experiments on cyclic animals (10, 23). Recently, Zhao et al. (24), studying the microenvironmental changes of the follicle in women with polycystic ovary syndrome, noted an increase in glycolysis with a decrease in lactate dehydrogenase (LDH) activity. Therefore, we assume that a similar study in cystic cows could clarify the OC pathogenesis, especially by Ovum Pick Up technique that allows researchers to avoid post-mortem changes.

Urea levels in the follicular fluid did not differ from that contained in the serum of normal animals, which is in agreement with the results of Leroy et al. (3). However, we noted a significant difference between the two biological fluids in the cystic animals. In fact, in the physiological case, several studies have noted higher urea concentrations in the liquid aspirated from follicles in development compared to the serum, probably due to active transport or local production of urea by follicular cells $(2,25)$. Therefore, the high concentrations recorded in the cystic fluid may be the result of an aberrant production in the walls of OC and/or excessive active transportation due to impaired blood-follicle barrier (which may explain the low urea content in the sera of cystic cows), favored by hypoglycemia recorded in cystic animals. This result requires more investigations (including the transport mechanism of the blood urea to the follicle, urea metabolism in follicular walls in the physiological and pathological case and the integrity of the blood-follicle barrier in OC).

In the present study, the concentrations of serum total protein were significantly higher than those of the follicular fluid. The result is consistent with those from other authors $(2,3)$. According to 
Leroy et al. (3), the average concentrations of total protein observed in the follicular fluid are $75-80 \%$ of that of serum. Wise (26) has identified a high correlation between the amounts of total protein in these two liquids and reported that many proteins in the follicular fluid come from the serum, probably by a procedure analogous to filtration. Unlike serum assay, statistical analysis revealed a significant difference between the protein content in follicular and cystic fluid. Since follicular fluid proteins originated from blood and follicular secretions, changes in protein levels in cystic fluid may reflect a modification in synthesis ability, in metabolism and in follicle walls structure which may have a role in the OC pathogenesis $(18,27)$. Some studies noted not only the difference in the total protein content, but also the modification of proteins quality. In cows, Maniwa et al. (27) identified eight additional proteins in the cystic fluid, whereas in sows, Sun et al. (18) have noted a difference of Retinol Binfing Protein-4 (RBP-4) and transferring levels which indicate the synthetic capacity and the follicle metabolic status, mainly in pathological cases. All these proteins are involved in the etiopathogenesis of OC $(18,27)$. A presence of apoptotic cells in the layers of granulosa cells that gradually disappear was also observed $(28,29)$. Therefore, intracellular proteins can pass through the degenerate granulosa cells to the follicle fluid. However, the possibility that these proteins are transported by the blood can't be eliminated. Therefore, it is important to determine the exact source of these proteins and the mechanism by which they are found in high levels in the follicular fluid of OC (27).

Cholesterol concentrations in the follicular fluid were significantly less than those in the serum. Aller et al. (2) and Hudson et al. (30) noted similar results. In camels, El-Bahr et al. (22) reported that cholesterol levels in serum were 3.5 times higher than those of the follicular fluid. Thereafter, they suggested that blood cholesterol is not the major metabolite available for steroidogenesis. Indeed, the granulosa cells have a large stock of cholesterol esters that are capable of providing cholesterol to ovarian function $(22,31)$. In addition, the cholesterol level is directly related to the energy state of animal. In fact, the presence of glucose in the ovarian tissue is important in acetate atoms incorporation in the sterol. Similarly, studies in ruminants have shown that glucose metabolism and cholesterol are closely related (32). In the present study, we found different results between blood and intrafollicular assays. The results showed a significant difference in cholesterol levels between follicular and cystic fluid while in serum, though no statistical difference was revealed between the cycled and cystic animals. This can be explained by cystic follicle microenvironment, which combines progressive degeneration of granulosa cells that contain cholesterol esters with low glucose levels recorded in cystic fluid. However, an alteration in the blood transportation mechanism is not excluded.

In addition, according to Rabiee and Lean (32), cholesterol and glucose uptake can be influenced by trophic hormones, including insulin and IGFI (Insulin Like Growth Factor I). Since these elements are critical to the development of ovarian structures and functions, their presence at low concentrations in the blood may affect the transovarian absorption of glucose and cholesterol, as well as steroidogenesis. In this study, the serum assay revealed statistical difference in insulin levels between cyclic and cystic animals. In contrast, insulin concentrations in follicular and cystic fluid were similar. The same results were reported by Hein et al. (33). The latter noted, in addition, changes in the insulinsignaling cascade in the ovary. These changes are related to the low expression of insulin receptors in granulosa cells. However, Vanholder et al. (34), in a similar approach, could not show such change except in cystic ovaries, which are functionally progesterone-active. They revealed a modification in $\mathrm{LH}$ receptor expression and alteration of the relationship between different receptors of insulin and IGF1.

No statistical difference between cortisol levels in follicular fluid and serum has been revealed. This result proves that intrafollicular cortisol is originated from serum because the ovary cannot produce glucocorticoids in vivo (35). Unlike serum assay that showed high levels of cortisol in cystic cows compared to cyclic ones, cortisol concentrations in follicular and cystic fluid were relatively low. Indeed, it is well known that glucocorticoids exert inhibitory effects on reproductive functions through alteration of $\mathrm{LH}$ secretion by the anterior pituitary. However, studies on the direct action of glucocorticoids on the ovarian level are controversial. Spicer and Zinn (36) found no active role of cortisol on the follicle functions. Similarly, Peter et al. (37) could not prove the effect of cortisol on aromatase activity. Thereafter, Kawate et al. (38) were able to reveal the inhibitory action of cortisol on estrogen synthesis and the number of $\mathrm{LH}$ receptors in vitro. In addition, it was shown that cortisol at physiological concentrations can directly affect ovarian function in cattle, especially the production of androstenedione by theca interna (7). Sunak et al. (39), in another approach (in 
vitro), reported that inactivation of Cortisol by 11-hydroxysteroid dehydrogenase b (11b-HSD) in the granulosa cells of pigs was significantly decreased, and suggested that the components that regulate cortisol metabolism by $11 \mathrm{~b}-\mathrm{HSD}$ can play a significant role in OC development. Finally, Amweg et al. (35) confirmed, in vitro, the expression of $\mathrm{ACTH}$ receptors in the bovine ovary, and noted after type identification that the 11b-HSD1 activity, which converts corticosterone into cortisol, was elevated in $\mathrm{OC}$ rather than in the tertiary follicle. This indicates a local role of cortisol in OC pathogenesis. According to the latter, since ovulation is an inflammatory process characterized by the synthesis of interleukins and prostaglandins, a massive release of anti-inflammatory glucocorticoids could limit this process in the ovary. However, extreme situations can affect the normal mechanism of ovulation and change the estrous cycle of the animal. Since high concentrations of glucocorticoids ( $\geq 36 \mathrm{ng} / \mathrm{ml}$ ) were required to inhibit $50 \%$ of aromatase activity and the increase of LH receptors in granulosa cells of the rat in vitro (7), we assume that the normal or decreased cortisol concentrations in cystic fluid are not involved in OC development. This is supported by the fact that most of cortisol (>90\%) is bound to the plasma proteins, mainly to globulin or $\mathrm{CBG}$ (cortisol-binding globulin) (36). The present study supports the concept that the role of cortisol in OC pathogenesis is limited to the inhibition of $\mathrm{LH}$ secretion by the anterior pituitary. This inhibition may also be the result of reduction in estrogen synthesis. This may be due to the gradual degradation of granulose cells. For that, this study needs to be completed by other experiments including those that determine the number of cortisol, estrogen and LH receptors, and aromatase activity in very young cystic follicles, preferably in vivo.

\section{CONCLUSION}

In summary, $\mathrm{OC}$ associated metabolic changes both in follicular fluid and in blood. They were characterized by low levels of glucose, total protein, cholesterol and cortisol in cystic fluid while urea concentrations were high. Serum assays revealed very low values of insulin and urea, whereas cortisol levels were relatively increased. The significant correlations that existed between follicular fluid and serum in normal cows were completely changed in cystic cows. Therefore, the current study needs to be completed by a deeper research concerning the blood-follicle-barrier.

\section{CONFLICT OF INTEREST}

The authors declared that they have no potential conflict of interest with respect to the authorship and/or publication of this article.

\section{ACKNOWLEDGEMENTS}

The authors are grateful to the staff of Nuclear Research Laboratory, Pathological Anatomy Laboratory of Douera (Algiers, Algeria) for their kind assistance during all analyses.

\section{REFERENCES}

1. Ghoneim, I.M., Waheed, M.M., El-Bahr, S.M., Alhaider, A.K., Al-Eknah, M.M. (2013). Comparison of some biochemical and hormonal constituents of oversized follicles and preovulatory follicles in camels (Camelus dromedarius). Theriogenology 79, 647-652.

https://doi.org/10.1016/j.theriogenology.2012.11.019 PMid:23290312

2. Aller, J.F., Callejas, S.S., Alberio, R.H. (2013). Biochemical and steroid concentrations in follicular fluid and blood plasma in different follicular waves of the estrous cycle from normal and superovulated beef cows. Anim Reprod Sci. 142, 113-120.

https://doi.org/10.1016/j.anireprosci.2013.09.009 PMid:24139762

3. Leroy, J.L.M.R., Vanholder, T., Delanghe, J.R., Opsomer, G., Van Soom, A., Bols, P.E.J., De Kruif, A. (2004). Metabolite and ionic composition of follicular fluid from different-sized follicles and their relationship to serum concentrations in dairy cows. Anim Reprod Sci. 80, 201-211.

https://doi.org/10.1016/S0378-4320(03)00173-8

4. Murayama, C., Yamasaki, E., Miyamoto, A., Shimizu, T. (2015). Effect in dedicator of cytokinesis 6 (DOCK6) on steroid production in theca cells of follicular cysts. Biochem Biophys Res Commun. 462, 415-419.

https://doi.org/10.1016/j.bbrc.2015.05.005

PMid:25976676

5. Diaz, P.U., Stangaferro, M.L., Matiller, V., Salvetti, N.R., Gareis, N.C., et al. (2015). Characterization of persistent follicles induced by prolonged treatment with progesterone in dairy cows: An experimental model for the study of ovarian follicular cysts. Theriogenology 84, 1149-1160. https://doi.org/10.1016/j.theriogenology.2015.06.015 PMid:26187329 
6. Kaneko J.J., Harvey H.W., Bruss M.L. (1997). Clinical biochemistry of domestic animals. In: Kaneko J.J., Harvey H.W., Bruss M.L. (Eds.), (p.932), San Diego: Academic Press.

7. Spicer, L.J., Chamberlain, C.S. (1998). Influence of cortisol on insulin- and insulin-like growth factor 1 (IGF-1)- induced steroid production and on IGF1 receptors in cultured bovine granulosa cells and thecal cells. Endocrine 9 (2) : 153-161. https://doi.org/10.1385/ENDO:9:2:153

8. Iwata, H., Inoue, J., Kimura, K., Kuge, T., Kuwayama, T., Monji, Y. (2006). Comparison between the characteristics of follicular fluid and the developmental competence of bovine oocytes. Anim Reprod Sci. 91, 215-223.

https://doi.org/10.1016/j.anireprosci.2005.04.006 PMid:15961265

9. Bellier, S. (2010). Interpretation and usual values of blood parameters in veterinary clinical biochemistry. Revue Francophone Des Laboratoires 420.

10. Acar, Baki, D., Birdane, M.K., Dogan, N., Gurler, H. (2013). Effect of the stage of estrous cycle on follicular population, oocyte yield and quality, and biochemical composition of serum and follicular fluid in Anatolian water buffalo. Anim Reprod Sci. $137,8-14$.

https://doi.org/10.1016/j.anireprosci.2012.12.004 PMid:23317849

11. Alves, B.G., Alves, K.A., Lúcio, A.C., Martins, M.C., Silva, T.H., Alves, B.G., et al. (2014). Ovarian activity and oocyte quality associated with the biochemical profile of serum and follicular fluid from Girolando dairy cows postpartum. Anim Reprod Sci. 146, 117-125.

https://doi.org/10.1016/j.anireprosci.2014.02.019 PMid:24674823

12. Duffield, T.F. (2000). Subclinical ketosis in lactating dairy cattle. Vet Clin North Am Food Anim Pract. 16, 231-253.

https://doi.org/10.1016/S0749-0720(15)30103-1

13. Yousefdoost, S., Samadi, F., Moghaddam, G., Hassani, S., Jafari Ahangari, Y. (2012). A comparison of hormonal, metabolite and mineral profiles between Holstein cows with and without ovarian cysts. IJAS. 2 (12): 1107-1115.

14. Probo, M., Comin, A., Cairoli, F., Faustini, M., Kindahl, H., De Amicis, I., Veronesi, M.C. (2011). Selected metabolic and hormonal profiles during maintenance of spontaneous ovarian cysts in dairy cows. Reprod Dom Anim. 46, 448-454. https://doi.org/10.1111/j.1439-0531.2010.01688.x PMid:20825583
15. Brugère-Picoux, J. (1995). Metabolic diseases and clinical biochemistry of the dairy cow. La dépêche technique. $46,30$.

16. Yotov, S.A., Atanasov, A.S., Georgiev, G.B., Dineva, J.D., Palova, N.A. (2014). Investigation on some biochemical parameters and effect of hormonal treatment in anoestrous dairy cows with cystic ovarian follicle. Asian Pac J Reprod. 3 (1): 41-45. https://doi.org/10.1016/S2305-0500(13)60183-9

17. Bender, K., Walsh, S., Evans, A.C.O., Fair, T., Brennan, L. (2010). Metabolite concentrations in follicular fluid may explain differences in fertility between heifers and lactating cows. Reproduction 139, 1047-1055.

https://doi.org/10.1530/REP-10-0068

PMid:20385782

18. Sun, Y.L., Ping, Z.G., Li, G.J., Sun, Y.F., Yi, K.L., Chen, L., Li, X.Y., Wang, X.L., Zhou, X. (2011). Comparative proteomic analysis of follicular fluids from normal and cystic follicles in sows. Reprod Dom Anim. 46, 889-895. https://doi.org/10.1111/j.1439-0531.2011.01760.x PMid:21366716

19. Fahiminiya, S., Gérard, N. (2010). Follicular fluid in mammals. Gynecol Obstet Fertil. 38, 402-404. https://doi.org/10.1016/j.gyobfe.2010.04.010 PMid:20576551

20. Khan, F.A., Das, G.K., Pande, M., Pathak, M.K., Sarkar, M. (2011). Biochemical and hormonal composition of follicular cysts in water buffalo (Bubalus bubalis). Anim Reprod Sci. 124, 61-64. https://doi.org/10.1016/j.anireprosci.2011.02.020 PMid:21392901

21. Arshad, H.M., Ahmad, N., Ziaur, R., Samad, H.A., Akhtar, N., Ali, S. (2005). Studies on some biochemical constituents of ovarian follicular fluid and peripheral blood in buffaloes. Pak Vet J. 25 (4): 155-158.

22. El-Bahr, S.M., Ghoneim, I.M., Waheed, M.M. (2015). Biochemical and hormonal analysis of follicular fluid and serum of female dromedary camels (Camelus dromedarius) with different sized ovarian follicles. Anim Reprod Sci. 159, 98-103. https://doi.org/10.1016/j.anireprosci.2015.06.002 PMid:26077770

23. Sutton-McDowall, M.L., Yelland, R., MacMillan, K.L., Robker, R.L., Thompson, J.G. A. (2014). Study relating the composition of follicular fluid and blood plasma from individual Holstein dairy cows to the in vitro developmental competence of pooled abattoirderived oocytes. Theriogenology 82, 95-103. https://doi.org/10.1016/j.theriogenology.2014.03.011 PMid:24746097 
24. Zhao, H., Zhao, Y., Li, T., Li, M., Li, J., Li, R., Liu, P., Yu, Y., Qiao, J. (2015). Metabolism alteration in follicular niche: The nexus among intermediary metabolism, mitochondrial function, and classic polycystic ovary syndrome. Free Radic Biol Med 86, $295-307$.

https://doi.org/10.1016/j.freeradbiomed.2015.05.013 PMid:26057937

25. Nandi, S., Girish, K.V., Manjunatha, B.M., Gupta, P.S.P. (2007). Biochemical composition of ovine follicular fluid in relation to follicle size. Dev Growth Differ. 49, 61-66.

https://doi.org/10.1111/j.1440-169X.2007.00901.x PMid:17227345

26. Wise, T. (1987). Biochemical analysis of bovine follicular fluid: albumin, total protein, lysosomal enzymes, ions, steroids and ascorbic acid content in relation to follicular size, rank, atresia classification and day of estrous cycle. J Anim Sci. 64, 1153-1169. https://doi.org/10.2527/jas1987.6441153x PMid:3571024

27. Maniwa, J., Izumi, S., Isobe, N., Terada, T. (2005). Studies on substantially increased proteins in follicular fluid of bovine ovarian follicular cysts using 2-D PAGE and MALDI-TOF MS. Reprod Biol Endocrinol. 3, 23.

https://doi.org/10.1186/1477-7827-3-23

PMid:15941490 PMCid:PMC1177988

28. Isobe, N., Yoshimura, Y. (2000). Localization of apoptotic cells in the cystic ovarian follicles of cows: a DNA-end labelling histochemical study. Theriogenology 53, 897-904. https://doi.org/10.1016/S0093-691X(00)00238-7

29. Braw-Tal, R., Pen, S., Roth, Z. (2009). Ovarian cysts in high-yielding dairy cows. Theriogenology 72 , 690-698.

https://doi.org/10.1016/j.theriogenology.2009.04.027 PMid:19559473

30. Hudson, N.L., Berg, M.C., Green, M.P., Back, P.J., Thorstensen, E.B., Peterson, A.J., Pitman, J.L., McNatty, K.P. (2014). The microenvironment of the ovarian follicle in the postpartum dairy cows: Effects on reagent transfer from cumulus cells to oocytes in vitro. Theriogenology $82,563-573$.

https://doi.org/10.1016/j.theriogenology.2014.05.016 PMid:24958635

31. Ménézo, Y., Guérin, P. (2001). In: C. Thibault, Levasseur, M.C. (Eds.), Reproduction in mammals and humans (pp.410-421). Paris: Co-ed INRAEllipses.
32. Rabiee, A.R., Lean, I.J. (2000). Uptake of glucose and cholesterol by the ovary of sheep and cattle and the influence of arterial LH concentrations. Anim Reprod Sci. 64, 199-209.

https://doi.org/10.1016/S0378-4320(00)00208-6

33. Hein, G.J., Panzani, C.G., Rodríguez, F.M., Salvetti, N.R., Díaz, P.U., Gareisa, N.C., Benítez, G.A., Ortega, H.H., Rey, F. (2015). Impaired insulin signaling pathway in ovarian follicles of cows with cystic ovarian disease. Anim Reprod Sci. 156, 64-74. https://doi.org/10.1016/j.anireprosci.2015.02.010 PMid:25813700

34. Vanholder, T., Leroy, J.L.M.R., Dewulf, J., Duchateau, L., Coryn, M., De Kruif, A., Opsomer, G. (2005). Hormonal and metabolic profiles of highyielding dairy cows prior to ovarian cyst formation or first ovulation post-partum. Reprod Dom Anim. 40, $460-467$.

https://doi.org/10.1111/j.1439-0531.2005.00601.x PMid:16149953

35. Amweg, A.N., Salvetti, N.R., Stangaferro, M.L., Paredes, A.H., Lara, H.H., Rodríguez, F.M., Ortega, H.H. (2013). Ovarian localization of

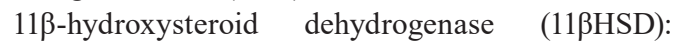
effects of ACTH stimulation and its relationship with bovine cystic ovarian disease. Domest Anim Endocrinol. 45, 126-140. https://doi.org/10.1016/j.domaniend.2013.07.001 PMid:23972491

36. Spicer, L.J., Zinn, S.A. (1987). Relationship between concentrations of cortisol in ovarian follicular fluid and various biochemical markers of follicular differentiation in cyclic and anovulatory cows. J Reprod Fert. 81, 221-226.

https://doi.org/10.1530/jrf.0.0810221

37. Peter, A.T., Peter, I., Simon, J.E., Luker C.W., Bosu, W.T.K. (1990). Site of action for endotoxin-induced cortisol release in the suppression of preovulatory luteinizing hormone surges. Theriogenology 33 (3): 637-643.

https://doi.org/10.1016/0093-691X(90)90540-A

38. Kawate, N., Inaba, T., Mori, J. (1993). Effects of cortisol on the amounts of estradiol-17 $\beta$ and progesterone secreted and the number of luteinizing hormone receptors in cultured bovine granulosa cells. Anim Reprod Sci. 32 (15): 15-25. https://doi.org/10.1016/0378-4320(93)90054-U 
39. Sunak, N., Green, D.F., Abeydeera, L.R., Thurston, L.M., Michael, A.E. (2007). Implication of cortisol and 11b-hydroxysteroid dehydrogenase enzymes in the development of porcine (Sus scrofa domestica) ovarian follicles and cysts. Reproduction 133, $1149-1158$.

https://doi.org/10.1530/REP-07-0003

PMid:17636169

Please cite this article as: Mimoune N., Kaidi R., Benaissa M. H., Bahouh M. W., Baazizi R., Azzouz M. Y. Metabolic profile comparison between follicular fluid and serum in normal cows and those affected by ovarian cysts. Mac Vet Rev 2019; 42 (1): 51-59. https://doi.org/10.2478/macvetrev-2018-0030 